\title{
Theoretical investigations on the structural, spectroscopic, electronic and thermodynamic properties of (3-Oxo-3H-benzo[f]chromen-1yl) methyl $\mathbf{N}, \mathbf{N}$-dimethylcarbamodithioate-1ex
}

\author{
Mehmet KarA $^{1}$, Meryem Evecen $^{2, *}$, Telhat ÖZdogan ${ }^{3}$ \\ ${ }^{1}$ Mechanical Engineering, Technology Faculty, Amasya University, 05100 Amasya, Turkey \\ ${ }^{2}$ Department of Physics, Faculty of Arts and Sciences, Amasya University, 05100 Amasya, Turkey \\ ${ }^{3}$ Department of Computer and Teaching Technology Education, Education Faculty, Amasya University, \\ 05100 Amasya, Turkey
}

\begin{abstract}
Hartree-Fock and Density Functional Theory (B3LYP, B3PW91) calculations for the ground state of (3-Oxo-3Hbenzo[f]chromen-1-yl) methyl N,N-dimethylcarbamodithioate have been presented and the calculated structural parameters and energetic properties have been compared with the available X-ray diffraction data. The vibrational frequencies have been calculated using optimized geometry of the molecule. The conformational properties of the molecule have been determined by computing molecular energy properties, in which torsional angle varied from $-180^{\circ}$ to $+180^{\circ}$ in steps of $10^{\circ}$. Moreover, natural bond orbital analysis and atomic charge analysis have been performed. Besides, HOMO and LUMO energies have been calculated and their pictures have been presented. Finally, molecular electrostatic potential and thermodynamic properties have been calculated. It is seen that the obtained theoretical results agree well with the available experimental values. In all the calculations, except for optimization and vibrational calculations, B3LYP level of theory with 6-311++G(d,p) basis set has been used.
\end{abstract}

Keywords: chromene; DFT; HF; NBO; HOMO; LUMO

\section{Introduction}

Priviliged structures or scaffolds were first studied by Evans et al. [1]. These structures can bind to a diverse range of targets with high affinities, thus enabling discovery of novel bioactive agents. Chromenes (benzopyrans) represent an important type of priviliged structures appearing in natural compounds and they possess interesting biological activities such as antitumor [2], antivascular [3], antimicrobial [4], antioxidant [5], TNF- $\alpha$ inhibitor [6], antifungal [7], anticoagulant [8], estrogenic [9], antiviral [10], anticancer [11, 12], anti-HIV [13], antitubercular [14], anti-inflammatory [15] and anticonvulsant $[16,17]$. Benzopyran derivatives are also used in the production of highly effective fluorescent

*E-mail: meryem.evecen@amasya.edu.tr dyes for synthetic fibers, daylight fluorescent pigments and electrophotographic and electroluminescent devices [18-23].

In the literature, coumarin compound, (3-Oxo-3H-benzo[f]chromen-1-yl) methyl $\mathrm{N}, \mathrm{N}$-dimethylcarbamodithioate was synthesized by Kumar et al. [21]. This compound was characterized by X-ray diffraction method and its structure was clarified with ${ }^{1} \mathrm{H}$ NMR and IR spectra by Mahabaleshwaraiah et al. [24]. To our knowledge, despite the importance mentioned above, there is a lack of theoretical calculations of conformational, natural bond orbital (NBO), molecular geometry, vibrational modes, molecular frontier orbital energy, electronic and thermodynamic properties of the title compound.

The aim of the this work is to to perform Mulliken population, natural population and conformational analyses as well as to describe and 
(a)

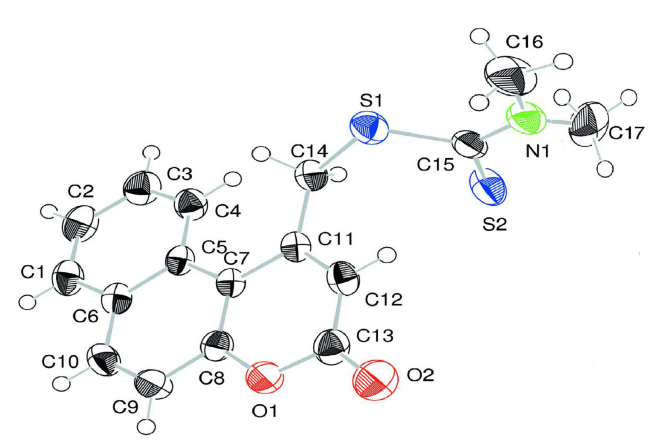

(b)

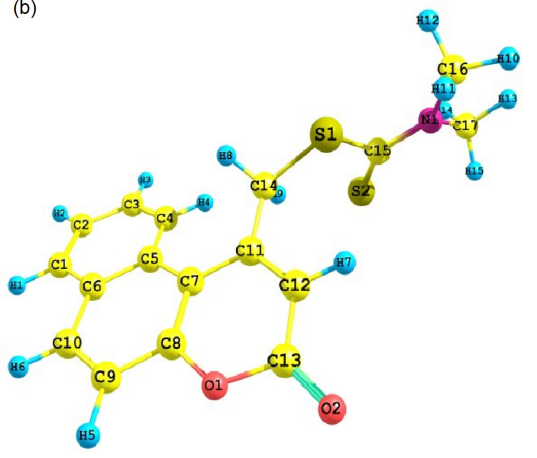

Fig. 1. (a) experimental structure [24], (b) optimized geometric structure of (3-Oxo-3H-benzo[f]chromen-1-yl) methyl N,N-dimethylcarbamodithioate compound (obtained at B3LYP/6-311++G(d,p) level). Visualization of this structure has been carried out with ChemCraft software [27].

characterize the molecular structure, vibrational frequencies, NBO, molecular frontier orbital energies (HOMO and LUMO), molecular electrostatic potential maps (MEP) and thermodynamic properties of (3-Oxo-3H-benzo[f]chromen-1-yl) methyl $\mathrm{N}, \mathrm{N}$-dimethylcarbamodithioate compound, using DFT (B3LYP, B3PW91) and HF calculations.

\section{Computational methods}

The initial molecular geometry of the studied molecule was taken from X-ray diffraction results [24] without any constraints. The geometry optimization is the basic building block of theoretical calculations. Therefore, we made geometry optimization for this molecule by $\mathrm{HF}$ and DFT (B3LYP and B3PW91) methods with $6-311++\mathrm{G}(\mathrm{d}, \mathrm{p})$ basis sets. Gaussian 09W program package was used in the HF and DFT calculations for the title compound [25]. The harmonic frequency calculations were performed at both HF and DFT levels with 6-311++G(d,p) basis sets using the optimized structural parameters. The obtained vibrational frequencies were scaled by a factor of 0.89 for HF, 0.96 for B3LYP and 0.957 for B3PW91. Vibrational band assignments were made using the Gauss-View molecular visualisation program [26]. In addition, electronic properties, such as natural bond orbital (NBO), charge analysis, HOMO-LUMO energies, and thermodynamic properties were calculated using DFT/B3LYP method.

\section{Results and discussion}

\subsection{Molecular structure}

The crystal structure of $\mathrm{C}_{17} \mathrm{H}_{15} \mathrm{NO}_{2} \mathrm{~S}_{2}$ is monoclinic and its space group is $\mathrm{P}_{2} 1 / \mathrm{n}$. The crystal structure parameters of the compound are $\mathrm{a}=14.1575$ (2) $\AA, \mathrm{b}=6.9399$ (1) $\AA$, $\mathrm{c}=15.9750(2) \AA, \beta=101.591(1)^{\circ}, \gamma=78.842$ $(1)^{\circ}$ and $\mathrm{V}=1537.56$ (4) $\AA^{3}$ [24]. In this molecule, the $3 \mathrm{H}$-benzo[f]-chromene ring system is distinctly twisted. The experimental structural parameters of the novel molecule are as follows: the dihedral angle between the pyran ring and its opposite benzene ring is $9.11(8)^{\circ}$, the N,N-dimethylcarbamodithioate residue lies almost perpendicular to the pyran ring (dihedral angle $\left.=85.15(7)^{\circ}\right)$

The molecular structure of the title compound has been optimized by GAUSSIAN 09W at HF and DFT levels using X-ray diffraction experimental data [24] without any constraints and is shown in Fig. 1 with atomic numbers [27]. The energies of the optimized structure obtained by HF, DFT-B3LYP and DFT-B3PW91 methods are $-44951.761 \mathrm{eV},-45136.013 \mathrm{eV}$ and $-5124.020 \mathrm{eV}$, respectively. Selected comparative structural parameters obtained from the optimization are presented in Table 1. 
Table 1. Selected molecular structure parameters.

\begin{tabular}{|c|c|c|c|c|}
\hline \multirow{2}{*}{ Parameters } & \multirow{2}{*}{ Experimental [24] } & \multicolumn{3}{|c|}{ This work (theoretical) } \\
\hline & & $\mathrm{HF}$ & B3LYP & B3PW91 \\
\hline \multicolumn{5}{|l|}{ Bond lengths $[\AA]$} \\
\hline S1-C15 & 1.784 & 1.786 & 1.815 & 1.801 \\
\hline S1-C14 & 1.800 & 1.812 & 1.825 & 1.811 \\
\hline S2-C15 & 1.664 & 1.668 & 1.669 & 1.663 \\
\hline $\mathrm{O} 1-\mathrm{C} 13$ & 1.367 & 1.346 & 1.394 & 1.388 \\
\hline $\mathrm{O} 1-\mathrm{C} 8$ & 1.374 & 1.345 & 1.358 & 1.351 \\
\hline $\mathrm{O} 2-\mathrm{C} 13$ & 1.207 & 1.181 & 1.204 & 1.202 \\
\hline $\mathrm{N} 1-\mathrm{C} 15$ & 1.327 & 1.328 & 1.350 & 1.346 \\
\hline N1-C16 & 1.460 & 1.464 & 1.467 & 1.458 \\
\hline N1-C17 & 1.465 & 1.465 & 1.468 & 1.459 \\
\hline $\mathrm{C} 1-\mathrm{C} 2$ & 1.356 & 1.359 & 1.374 & 1.372 \\
\hline C5-C6 & 1.424 & 1.413 & 1.434 & 1.431 \\
\hline $\mathrm{C} 5-\mathrm{C} 7$ & 1.453 & 1.454 & 1.452 & 1.447 \\
\hline $\mathrm{C} 7-\mathrm{C} 8$ & 1.387 & 1.371 & 1.398 & 1.396 \\
\hline $\mathrm{C} 11-\mathrm{C} 14$ & 1.514 & 1.519 & 1.517 & 1.511 \\
\hline \multicolumn{5}{|l|}{ Bond angles $\left[{ }^{\circ}\right]$} \\
\hline C15-S1-C14 & 103.500 & 105.175 & 102.903 & 102.453 \\
\hline C13-O1-C8 & 121.630 & 123.410 & 122.528 & 122.536 \\
\hline C15-N1-C17 & 120.920 & 119.243 & 119.007 & 118.851 \\
\hline C16-N1-C17 & 114.640 & 117.995 & 117.790 & 118.072 \\
\hline C5-C7-C11 & 127.610 & 127.834 & 127.389 & 127.293 \\
\hline $\mathrm{O} 1-\mathrm{C} 8-\mathrm{C} 7$ & 123.370 & 123.504 & 123.182 & 123.250 \\
\hline C12-C11-C14 & 119.090 & 120.287 & 119.832 & 119.858 \\
\hline $\mathrm{O} 2-\mathrm{C} 13-\mathrm{O} 1$ & 117.550 & 119.135 & 117.975 & 117.952 \\
\hline $\mathrm{O} 1-\mathrm{C} 13-\mathrm{C} 12$ & 115.970 & 115.104 & 114.576 & 114.616 \\
\hline C11-C14-S1 & 116.430 & 117.221 & 116.547 & 116.222 \\
\hline N1-C15-S1 & 113.330 & 113.256 & 112.548 & 112.569 \\
\hline $\mathrm{S} 2-\mathrm{C} 15-\mathrm{S} 1$ & 122.510 & 122.956 & 123.816 & 123.961 \\
\hline \multicolumn{5}{|l|}{ Torsion angles $\left[{ }^{\circ}\right]$} \\
\hline C6-C5-C7-C11 & -171.940 & -170.465 & -168.549 & -168.067 \\
\hline C5-C7-C8-O1 & 176.450 & 174.828 & 173.503 & 173.426 \\
\hline $\mathrm{C} 8-\mathrm{O} 1-\mathrm{C} 13-\mathrm{O} 2$ & -176.030 & -172.990 & -172.990 & -172.832 \\
\hline C7-C11-C14-S1 & 158.210 & 158.877 & 155.798 & 155.586 \\
\hline C15-S1-C14-C11 & 86.480 & 97.353 & 105.834 & 107.283 \\
\hline C16-N1-C15-S2 & 178.010 & 178.745 & 177.490 & 177.353 \\
\hline C17-N1-C15-S1 & -179.390 & -177.760 & -175.282 & -175.203 \\
\hline C14-S1-C15-N1 & -173.890 & -178.865 & -176.895 & -176.664 \\
\hline
\end{tabular}


Table 2. Comparison of the experimental and calculated vibrational frequencies $\left[\mathrm{cm}^{-1}\right]$.

\begin{tabular}{|c|c|c|c|c|}
\hline Assignments & Experimental [24] & $\mathrm{HF}$ & B3LYP & B3PW91 \\
\hline$v(\mathrm{C}-\mathrm{H}) \mathrm{R} \mathrm{s}$ & - & 2984 & 3063 & 3064 \\
\hline$v(\mathrm{C}-\mathrm{H}) \mathrm{R}$ as & - & 2972 & 3048 & 3048 \\
\hline$v\left(\mathrm{C}-\mathrm{H}_{3}\right)$ as & - & 2949 & 3021 & 3022 \\
\hline$v\left(\mathrm{C}-\mathrm{H}_{3}\right)$ as & - & 2914 & 3009 & 2980 \\
\hline$v\left(\mathrm{C}-\mathrm{H}_{3}\right) \mathrm{s}$ & - & 2883 & 2920 & 2916 \\
\hline$v\left(\mathrm{C}-\mathrm{H}_{3}\right) \mathrm{s}$ & - & 2852 & 2903 & 2900 \\
\hline$v\left(\mathrm{C}-\mathrm{H}_{2}\right) \mathrm{s}$ & - & 2838 & 2866 & 2824 \\
\hline$v(\mathrm{C}=\mathrm{O})$ & 1708.6 & 1766 & 1728 & 1744 \\
\hline$v(\mathrm{C}=\mathrm{C}) \mathrm{R}$ & - & 1628 & 1591 & 1601 \\
\hline$v(\mathrm{C}-\mathrm{C}) \mathrm{R}$ & - & 1586 & 1580 & 1588 \\
\hline$v(\mathrm{C}=\mathrm{C}) \mathrm{R}$ & - & 1548 & 1517 & 1527 \\
\hline$v(\mathrm{C}=\mathrm{C}) \mathrm{R}$ & - & 1488 & 1488 & 1491 \\
\hline$\omega\left(\mathrm{C}-\mathrm{H}_{3}\right)$ & - & 1480 & 1471 & 1467 \\
\hline$\gamma(\mathrm{C}-\mathrm{H})$ & - & 1436 & 1426 & 1425 \\
\hline$v(\mathrm{C}=\mathrm{C}) \mathrm{R}+\omega\left(\mathrm{C}-\mathrm{H}_{2}\right)$ & - & 1367 & 1366 & 1355 \\
\hline$v(\mathrm{C}-\mathrm{N})+\omega\left(\mathrm{C}-\mathrm{H}_{3}\right)+v(\mathrm{C}-\mathrm{O})$ & - & 1344 & 1341 & 1347 \\
\hline$\omega\left(\mathrm{C}-\mathrm{H}_{2}\right)+v(\mathrm{C}-\mathrm{C}) \mathrm{R}+v(\mathrm{C}-\mathrm{N})$ & - & 1337 & 1337 & 1329 \\
\hline$v(\mathrm{C}-\mathrm{C}) \mathrm{R}+\omega\left(\mathrm{C}-\mathrm{H}_{2}\right)$ & - & 1255 & 1313 & 1288 \\
\hline$v(\mathrm{C}-\mathrm{O}-\mathrm{C})$ & 1279 & 1195 & 1290 & 1258 \\
\hline$v(\mathrm{C}-\mathrm{N})+v(\mathrm{C}=\mathrm{S})$ & 1251 & 1137 & 1233 & 1244 \\
\hline$\delta\left(\mathrm{C}-\mathrm{H}_{3}\right)+\delta\left(\mathrm{C}-\mathrm{H}_{2}\right)$ & - & 1030 & 1223 & 1179 \\
\hline$\Omega\left(\mathrm{C}-\mathrm{H}_{2}\right)+\alpha(\mathrm{C}-\mathrm{H}) \mathrm{R}$ & - & 1011 & 1169 & 1166 \\
\hline$v(\mathrm{C}-\mathrm{O})+\alpha(\mathrm{C}-\mathrm{H})$ & - & 962 & 1106 & 1131 \\
\hline$\gamma\left(\mathrm{C}-\mathrm{H}_{3}\right)$ & - & 957 & 1025 & 1123 \\
\hline$\Omega\left(\mathrm{C}-\mathrm{H}_{2}\right)+\alpha(\mathrm{C}-\mathrm{H}) \mathrm{R}$ & - & 907 & 973 & 1088 \\
\hline$v(\mathrm{C}-\mathrm{O})$ & 1036 & 904 & 967 & 979 \\
\hline$\delta(\mathrm{C}-\mathrm{H})$ & - & 856 & 940 & 953 \\
\hline$v(\mathrm{C}-\mathrm{N})+v(\mathrm{C}-\mathrm{S})+\omega\left(\mathrm{C}-\mathrm{H}_{2}\right)$ & - & 834 & 951 & 967 \\
\hline$v(\mathrm{C}-\mathrm{O}) \mathrm{R}$ & - & 750 & 874 & 880 \\
\hline$v(\mathrm{C}-\mathrm{N})+v(\mathrm{C}-\mathrm{S})$ & 842 & 740 & 831 & 848 \\
\hline$\omega(\mathrm{C}-\mathrm{H}) \mathrm{R}$ & - & 717 & 799 & 796 \\
\hline$\omega(\mathrm{C}-\mathrm{H}) \mathrm{R}+v\left(\mathrm{~S}-\mathrm{CH}_{2}\right)$ & - & 572 & 727 & 752 \\
\hline$v(\mathrm{C}-\mathrm{S})$ & 660 & 560 & 672 & 563 \\
\hline$\gamma\left(\mathrm{C}-\mathrm{H}_{2}\right)$ & - & 432 & 365 & 366 \\
\hline
\end{tabular}

$v$-stretching; $\delta$ - twisting; $\gamma$ - rocking; $\omega$ - wagging; $\alpha$ - scissoring; $s$ - symmetric; as - asymmetric; $\mathrm{R}$ - ring.

Taking into account these results we can conclude that B3LYP/6-311++G(d,p) method can be used as the main reference. It is also well known from the literature that DFT-optimized bond lengths are usually longer and more accurate than HF due to the electron correlation included in DFT [28].
The bond lengths, angles and dihedral angles are presented in Table 1. It is seen from the Table that the calculated bond lengths are slightly larger than the corresponding experimental values. This discrepancy may originate from the fact that the theoretical calculations were performed for the gaseous phase whereas the experimental results 
were obtained for the solid phase [29]. Another reason can be the change in charge distribution on the carbon atom of the benzene ring [30]. The carbonhydrogen bond lengths are given as standard values during the solvation of the crystal structure by SHELXS97 [31, 32]. In Table 1, we did not give them because of the disprecancies in the bond lengths between carbon and hydrogen atoms.

From Table 1 we can see that the calculated bond angles are in agreement with the experimental results. The only discrepancy occurs for the angle C16-N1-C17, which we think may originate from sharp in-plane and out-of-plane vibrations of the methyl group bonded to nitrogen atom. We also see that all the calculated dihedral angles are in a good agreement with the experimental results.

The calculated geometrical parameters obtained by HF, DFT/B3LYP and DFT/B3PW91 methods represent a good approximation and they are the bases for calculating other parameters, such as vibrational frequencies, conformational analysis, frontier molecular orbitals, electronic and thermodynamic properties.

\subsection{Vibrational spectra}

Harmonic vibrational frequencies were calculated using HF, DFT/B3LYP and DFT/B3PW91 with the $6-311++G(d, p)$ basis set. Stimulated IR spectra of the title compound are shown in Fig. 2. The calculated and available experimental frequencies of the IR spectra of the title compound are presented in Table 2 with probable assignments obtained by the use of Gauss-View molecular visualisation program. Theoretical vibrational frequencies of the title compound obtained by the three methods agree well with experimental data.

The studied title compound $\mathrm{C}_{17} \mathrm{H}_{15} \mathrm{NO}_{2} \mathrm{~S}_{2}$ includes 37 atoms and therefore undergoes 105 normal modes of vibrations. For fitting the theoretical wavenumbers to the experimental ones, an overall scaling factor has been introduced by using a least-square optimization of the computed values to the experimental ones. Vibrational frequencies have been scaled as $0.890,0.960$ and

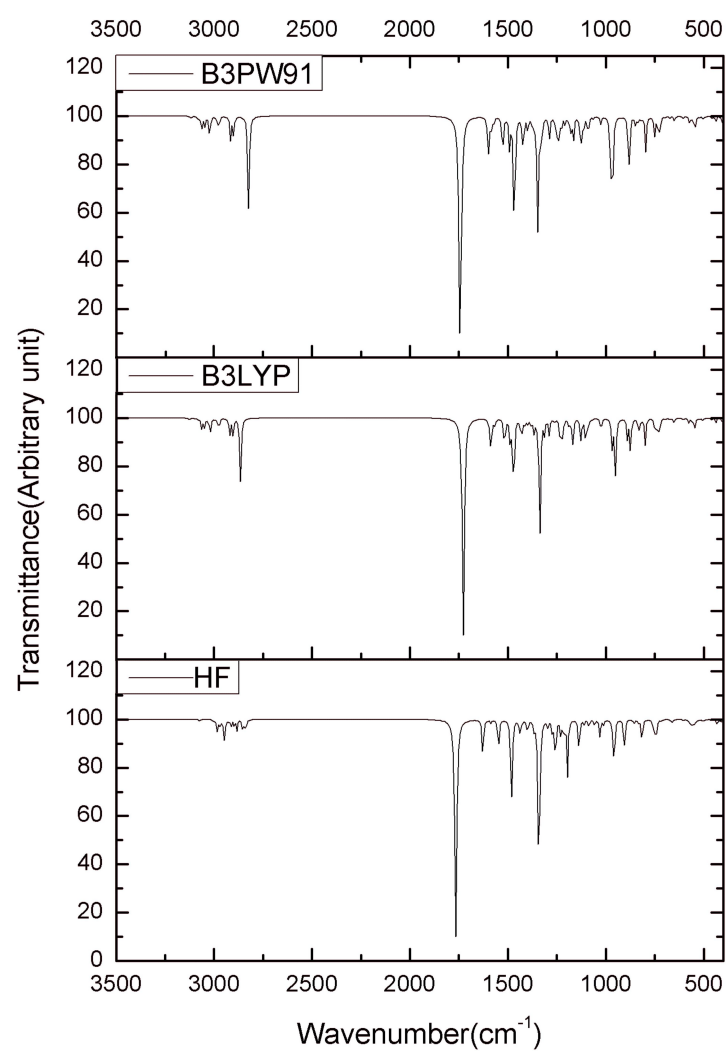

Fig. 2. Calculated FT-IR spectrum of (3-Oxo-3H-benzo[f]chromen-1-yl) methyl $\mathrm{N}, \mathrm{N}$-dimethylcarbamodithioate compound.

0.957 for HF, B3LYP and B3PW91, respectively, with 6-311++G(d,p) basis set [33, 34].

The IR spectra contain some characteristic bands of the stretching vibrations of $\mathrm{C}-\mathrm{H}, \mathrm{C}-\mathrm{H}_{3}$, $\mathrm{C}-\mathrm{H}_{2}, \mathrm{C}=\mathrm{O}, \mathrm{C}-\mathrm{O}, \mathrm{C}-\mathrm{C}, \mathrm{C}-\mathrm{N}$ and $\mathrm{C}-\mathrm{S}$ groups, which were analysed in a detailed way.

Among the vibrations in molecules, the $\mathrm{C}-\mathrm{H}$ vibration has a well-known characteristic frequency, and in the region of $3100 \mathrm{~cm}^{-1}$ to $3000 \mathrm{~cm}^{-1}$, which is the region characteristic for ready identification of $\mathrm{C}-\mathrm{H}$ stretching vibrations in plane, multiple weak bonds are expected for aromatic compounds [35]. The bands in this region are not affected by the nature of the substituents.

Looking at Table 2, we see that the calculated $\mathrm{C}-\mathrm{H}$ aromatic streching intensities have a medium intensity and the results obtained by three different methods are $2984 \mathrm{~cm}^{-1}$ to $2972 \mathrm{~cm}^{-1}$ 
for HF, $3063 \mathrm{~cm}^{-1}$ to $3048 \mathrm{~cm}^{-1}$ for B3LYP and $3064 \mathrm{~cm}^{-1}$ to $3048 \mathrm{~cm}^{-1}$ for B3PW91. As can be seen, these intensities are in the expected region. It is known that $\mathrm{C}-\mathrm{H}$ in-plane and out-of-plane bending vibrations lie in the range of $1300 \mathrm{~cm}^{-1}$ to $1000 \mathrm{~cm}^{-1}$ and $950 \mathrm{~cm}^{-1}$ to $800 \mathrm{~cm}^{-1}$ [3638]. We have calculated four $\mathrm{C}-\mathrm{H}$ in-plane bending vibrations of the title compound by three different methods as $1436 \mathrm{~cm}^{-1}, 1011 \mathrm{~cm}^{-1}$, $962 \mathrm{~cm}^{-1}$ and $907 \mathrm{~cm}^{-1}$ by HF; $1426 \mathrm{~cm}^{-1}$, $1169 \mathrm{~cm}^{-1}, 1106 \mathrm{~cm}^{-1}$ and $973 \mathrm{~cm}^{-1}$ by B3LYP, and $1425 \mathrm{~cm}^{-1}, 1166 \mathrm{~cm}^{-1}, 1131 \mathrm{~cm}^{-1}$ and $1088 \mathrm{~cm}^{-1}$ by B3PW91. An out-of-plane twistingbending mode has been calculated at $856 \mathrm{~cm}^{-1}$ by HF, $940 \mathrm{~cm}^{-1}$ by B3LYP and $953 \mathrm{~cm}^{-1}$ by B3PW91 and two out-of-plane waggings have been calculated at $717 \mathrm{~cm}^{-1}$ and $572 \mathrm{~cm}^{-1}$ by $\mathrm{HF}$, $799 \mathrm{~cm}^{-1}$ and $727 \mathrm{~cm}^{-1}$ by B3LYP and $796 \mathrm{~cm}^{-1}$ and $752 \mathrm{~cm}^{-1}$ by B3PW91.

The studied title compound has two $\mathrm{C}-\mathrm{H}_{3}$ groups. The $\mathrm{C}-\mathrm{H}$ methyl group stretching vibrations, especially observed in the range of $3000 \mathrm{~cm}^{-1}$ to $2900 \mathrm{~cm}^{-1}$, are highly localized $[39,40]$. In this study, the asymmetric bands with high peaks have been found at $2949 \mathrm{~cm}^{-1}$ and $2914 \mathrm{~cm}^{-1}$ by HF, 3021 and $3009 \mathrm{~cm}^{-1}$ by B3LYP and $3022 \mathrm{~cm}^{-1}$ and $2980 \mathrm{~cm}^{-1}$ by B3PW91, while symmetric stretching vibrations have been found at $2883 \mathrm{~cm}^{-1}$ and $2852 \mathrm{~cm}^{-1}$ by HF, $2920 \mathrm{~cm}^{-1}$ and $2903 \mathrm{~cm}^{-1}$ by B3LYP and $2916 \mathrm{~cm}^{-1}$ and $2900 \mathrm{~cm}^{-1}$ by B3PW91. In this investigation, two $\mathrm{C}-\mathrm{H}_{3}$ wagging vibrations have been found at $1480 \mathrm{~cm}^{-1}$ and $1344 \mathrm{~cm}^{-1}$ by HF, $1471 \mathrm{~cm}^{-1}$ and $1341 \mathrm{~cm}^{-1}$ by B3LYP and $1467 \mathrm{~cm}^{-1}$ and $1347 \mathrm{~cm}^{-1}$ by B3PW91. The twisting-bending mode have been found at $1030 \mathrm{~cm}^{-1}$ by HF, $1223 \mathrm{~cm}^{-1}$ by B3LYP, and $1179 \mathrm{~cm}^{-1}$ by B3PW91. We have observed rocking frequency at $957 \mathrm{~cm}^{-1}$ by HF, $1025 \mathrm{~cm}^{-1}$ by B3LYP and $1123 \mathrm{~cm}^{-1}$ by B3PW91, which is in agreement with the literature [41, 42].

In this work, six wagging and one stretching, twisting and rocking methylene vibrations are observed. Generally, the symmetric $\mathrm{C}-\mathrm{H}_{2}$ stretching vibrations are observed between $3000 \mathrm{~cm}^{-1}$ and $2900 \mathrm{~cm}^{-1}$ [43]. In accordance with this, $\mathrm{C}-\mathrm{H}_{2}$ symmetric mode has been found at $2838 \mathrm{~cm}^{-1}$ by HF, $2866 \mathrm{~cm}^{-1}$ by B3LYP and $2824 \mathrm{~cm}^{-1}$ by B3PW91. Six $\mathrm{C}-\mathrm{H}_{2}$ wagging out-of-plane deformation vibrations have been obtained at $1367 \mathrm{~cm}^{-1}, 1337 \mathrm{~cm}^{-1}, 1255 \mathrm{~cm}^{-1}, 1011 \mathrm{~cm}^{-1}$, $907 \mathrm{~cm}^{-1}$ and $834 \mathrm{~cm}^{-1}$ by HF; $1366 \mathrm{~cm}^{-1}$, $1337 \mathrm{~cm}^{-1}, 1313 \mathrm{~cm}^{-1}, 1169 \mathrm{~cm}^{-1}, 973 \mathrm{~cm}^{-1}$ and $951 \mathrm{~cm}^{-1}$ by B3LYP, and $1355 \mathrm{~cm}^{-1}$, $1329 \mathrm{~cm}^{-1}, 1288 \mathrm{~cm}^{-1}, 1166 \mathrm{~cm}^{-1}, 1088 \mathrm{~cm}^{-1}$ and $967 \mathrm{~cm}^{-1}$ by B3PW91. Twisting and rocking bands are observed at $1030 \mathrm{~cm}^{-1}$ and $432 \mathrm{~cm}^{-1}$ by HF, $1223 \mathrm{~cm}^{-1}$ and $365 \mathrm{~cm}^{-1}$ by B3LYP and $1179 \mathrm{~cm}^{-1}$ and $366 \mathrm{~cm}^{-1}$ by B3PW91.

These vibrations are more effective for analyzing various factors in ring aromatic compounds. Because of different electronegativities of $\mathrm{C}$ and $\mathrm{O}$, the $\mathrm{C}=\mathrm{O}$ bond reduces the frequencies of the $\mathrm{C}=\mathrm{O}$ stretching absorption to a greater degree than intermolecular $\mathrm{H}$ bonding does. The lone pair of electrons on oxygen also determines the nature of the carbonyl groups. The $\mathrm{C}=\mathrm{O}$ vibration appearing in the expected range shows that it is not much affected by other vibrations, as mentioned in literature [44]. As is well-known, compounds including carbonyl group, show $\mathrm{C}=\mathrm{O}$ streching vibrations in the region $1920 \mathrm{~cm}^{-1}$ to $1640 \mathrm{~cm}^{-1}$. In the present study, $\mathrm{C}=\mathrm{O}$ strong stretching vibration has been identified at $1766 \mathrm{~cm}^{-1}$ by $\mathrm{HF}, 1728 \mathrm{~cm}^{-1}$ by B3LYP, and at $1744 \mathrm{~cm}^{-1}$ by B3PW91, which is in the expected region [45] and in good agreement with the experimental value of $1708.6 \mathrm{~cm}^{-1}$ (Table 2).

$\mathrm{C}-\mathrm{O}$ stretching band of the aromatic ring in IR spectrum is characterized by the frequencies around $1270 \mathrm{~cm}^{-1}$ to $1230 \mathrm{~cm}^{-1}$ [46]. For aromatic rings, the $\mathrm{C}-\mathrm{O}$ vibrations are observed at $1195 \mathrm{~cm}^{-1}\left(1290 \mathrm{~cm}^{-1}, 1258 \mathrm{~cm}^{-1}\right)$ and $904 \mathrm{~cm}^{-1}$ $\left(967 \mathrm{~cm}^{-1}, 979 \mathrm{~cm}^{-1}\right)$ by HF (B3LYP, B3PW91) method. These assignments were also supported by the experimental values of $1279 \mathrm{~cm}^{-1}$ and $1036 \mathrm{~cm}^{-1}$.

The $\mathrm{C}-\mathrm{N}$ stretching vibrations are observed in $1382 \mathrm{~cm}^{-1}$ to $1266 \mathrm{~cm}^{-1}$ [45], $1150 \mathrm{~cm}^{-1}$ to $1120 \mathrm{~cm}^{-1}$ [47], and $1248 \mathrm{~cm}^{-1}$ to $1199 \mathrm{~cm}^{-1}$ [48]. In this study, we have observed the $\mathrm{C}-\mathrm{N}$ stretching vibrations at 
$1344 \mathrm{~cm}^{-1}, 1337 \mathrm{~cm}^{-1}, 1137 \mathrm{~cm}^{-1}, 834 \mathrm{~cm}^{-1}$ and $740 \mathrm{~cm}^{-1}$ by HF; $1341 \mathrm{~cm}^{-1}, 1337 \mathrm{~cm}^{-1}$, $1233 \mathrm{~cm}^{-1}, 951 \mathrm{~cm}^{-1}$ and $831 \mathrm{~cm}^{-1}$ by B3LYP; and $1347 \mathrm{~cm}^{-1}, 1329 \mathrm{~cm}^{-1}, 1244 \mathrm{~cm}^{-1}, 967 \mathrm{~cm}^{-1}$ and $848 \mathrm{~cm}^{-1}$ by B3PW91. These results are in the expected region and agree well with the experimental result $842 \mathrm{~cm}^{-1}$ (Table 2).

The aromatic stretching vibrations are very prominent, as the involved double $\mathrm{C}=\mathrm{C}$ bond is in conjugation with the ring. The ring $\mathrm{C}=\mathrm{C}$ and $\mathrm{C}-\mathrm{C}$ stretching vibrations were observed in the region of $1620 \mathrm{~cm}^{-1}$ to $1390 \mathrm{~cm}^{-1}$ by Arivazhagan et al. [49] and in the region of $1625 \mathrm{~cm}^{-1}$ to $1280 \mathrm{~cm}^{-1}$ by Varasanyi et al. [50]. In the present work, we have observed ring $\mathrm{C}=\mathrm{C}$ and $\mathrm{C}-\mathrm{C}$ stretching vibration frequencies at $1628 \mathrm{~cm}^{-1}, 1586 \mathrm{~cm}^{-1}$, $1548 \mathrm{~cm}^{-1}, 1488 \mathrm{~cm}^{-1}, 1367 \mathrm{~cm}^{-1}, 1337 \mathrm{~cm}^{-1}$ and $1255 \mathrm{~cm}^{-1}$ by HF, $1591 \mathrm{~cm}^{-1}, 1580 \mathrm{~cm}^{-1}$, $1517 \mathrm{~cm}^{-1}, 1488 \mathrm{~cm}^{-1}, 1366 \mathrm{~cm}^{-1}, 1337 \mathrm{~cm}^{-1}$ and $1313 \mathrm{~cm}^{-1}$ by B3LYP, and $1601 \mathrm{~cm}^{-1}$, $1588 \mathrm{~cm}^{-1}, 1527 \mathrm{~cm}^{-1}, 1491 \mathrm{~cm}^{-1}, 1355 \mathrm{~cm}^{-1}$, $1329 \mathrm{~cm}^{-1}$ and $1288 \mathrm{~cm}^{-1}$ by B3PW91.

The absorption bands of $\mathrm{C}=\mathrm{S}$ group were observed by Silverstein et al. in the region of $1563 \mathrm{~cm}^{-1}$ to $700 \mathrm{~cm}^{-1}$ [51] and the absorption bands of $\mathrm{C}-\mathrm{S}$ group were found in the range of $930 \mathrm{~cm}^{-1}$ to $670 \mathrm{~cm}^{-1}$ with a moderate intensity $[52,53]$. The experimental $\mathrm{C}=\mathrm{S}$ vibration mode was observed at $1251 \mathrm{~cm}^{-1}$ while $\mathrm{C}-\mathrm{S}$ vibration modes were at $842 \mathrm{~cm}^{-1}$ and $660 \mathrm{~cm}^{-1}$ [24]. In this work, we have calculated $\mathrm{C}=\mathrm{S}$ vibrations at $1137 \mathrm{~cm}^{-1}, 1233 \mathrm{~cm}^{-1}$ and $1244 \mathrm{~cm}^{-1}$ by HF, B3LYP and B3PW91, respectively, while $\mathrm{C}-\mathrm{S}$ vibrations were obtained at $834 \mathrm{~cm}^{-1}, 740 \mathrm{~cm}^{-1}$, $572 \mathrm{~cm}^{-1}$ and $560 \mathrm{~cm}^{-1}$ by HF; $951 \mathrm{~cm}^{-1}$, $831 \mathrm{~cm}^{-1}, 727 \mathrm{~cm}^{-1}$ and weak intensity $672 \mathrm{~cm}^{-1}$ by B3LYP; and $967 \mathrm{~cm}^{-1}, 848 \mathrm{~cm}^{-1}, 752 \mathrm{~cm}^{-1}$ and $563 \mathrm{~cm}^{-1}$ by B3PW91. The calculated results showed slight deviations from experimental values due to hydrogen bonding interactions. We can say that these vibrations coincide satisfactorily with the literature and experimental values (Table 2).

FT-IR spectrum of the title compound has been obtained by HF, B3LYP and B3PW91 methods, and is shown in Fig. 2. It can be concluded from Fig. 2 and Table 2 that except for HF method, other methods give the results which are in good agreement with each other and the experiment. The exception for HF may be due to the fact that HF takes no electron correlation into account. It is seen from Table 2 that the calculated vibrational frequencies of the title compund agree well with the available experimental results. From this, we can conclude that other vibrational frequencies presented in this work can be a reference for experimentalists.

\subsection{Conformational analysis}

In order to define the preferential position of low energy structures, computations were performed using B3LYP/6-311++G(d,p) as a function of selected degrees of torsional freedom $\mathrm{T}(\mathrm{C} 11-\mathrm{C} 14-\mathrm{S} 1-\mathrm{C} 15)$. The respective value of selected degrees of torsional freedom, $\mathrm{T}(\mathrm{C} 11-\mathrm{C} 14-$ $\mathrm{S} 1-\mathrm{C} 15)$, is $86.48^{\circ}$ in X-ray structure [24], whereas the corresponding value in DFT optimized geometry is $105.834^{\circ}$. In Fig. 3, the molecular energy profiles with respect to rotations about the selected torsion angles are shown. It is seen from Fig. 3 that the low energy domains for T(C11-C14-S1-C15) are located at $70^{\circ}$ and $180^{\circ}$. Energy difference between the most favorable and unfavorable conformers is calculated as $1.56 \mathrm{eV}$, when selected degree of torsional freedom is considered.

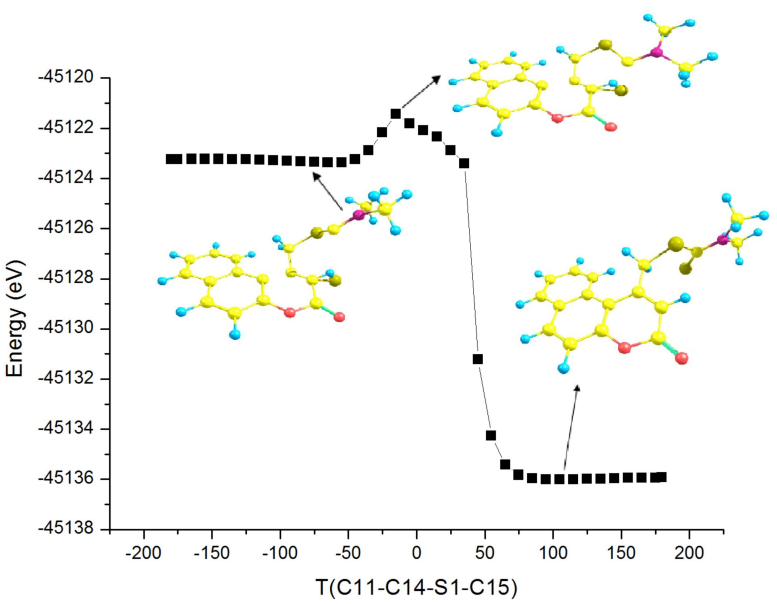

Fig. 3. Potential energy profile obtained using B3LYP/6-311++G(d.p) method for the internal rotation around the $\mathrm{C} 14-\mathrm{S} 1$ bond of (3-Oxo-3H-benzo[f]chromen-1-yl) methyl N,Ndimethylcarbamodithioate compound. 
It must be noted that the selected torsion angle in the crystal structure of the title compound is near to its global minimum value.

\subsection{Natural bond orbital analysis}

In order to investigate charge transfer or conjugative interaction in molecular systems, we have executed natural bond orbital (NBO) analysis using Gaussian 09W program. Some electron donor orbitals, acceptor orbitals and the interacting stabilization energy resulting from the second-order micro-disturbance theory have been reported in the literature [54, 55].

More intensive interactions between electron donors and electron acceptors depend on larger $\mathrm{E}^{(2)}$ value, i.e. the more donating tendency from electron donors to electron acceptors, the greater the extent of conjugation of the whole system [56]. The stabilization energy $\mathrm{E}^{(2)}$ associated with $\mathrm{i}$ (donor) $\rightarrow \mathrm{j}$ (acceptor) delocalization is obtained by $[57,58]$ :

$$
E^{(2)}=-q_{i} \frac{\left(F_{i j}\right)^{2}}{\varepsilon_{j}-\varepsilon_{i}}
$$

where $q_{i}$ is the donor orbital occupancy, $\epsilon_{i}, \epsilon_{j}$ are orbital energies and $F_{i j}$ is the off-diagonal NBO Fock matrix element. For investigating the intramolecular interactions, second-order perturbation theory was used for obtaining stabilization energies of the title compound. We found from the NBO analysis that the intramolecular interactions formed by the orbital overlap between bonding $(\mathrm{C}-\mathrm{S}),(\mathrm{C}-\mathrm{O}),(\mathrm{C}-\mathrm{N}),(\mathrm{C}-\mathrm{C})$ and $(\mathrm{C}-\mathrm{H})$ and anti-bonding $(\mathrm{C}-\mathrm{O}),(\mathrm{C}-\mathrm{N}),(\mathrm{C}-\mathrm{C})$ and $(\mathrm{C}-\mathrm{H})$ orbitals resulting from intramolecular charge transfer, cause stabilization of the compound. Selected second-order perturbation energies $\mathrm{E}^{(2)}$ associated with $\mathrm{i} \rightarrow \mathrm{j}$ delocalization in gas phase have been tabulated in Table 3. The stabilization energies larger than $300 \mathrm{kcal} / \mathrm{mol}$ have been listed in the table presented in the literature [59]. In electron density (ED), these interactions are observed as an increase in $(\mathrm{C}-\mathrm{S}),(\mathrm{C}-\mathrm{C})$ and (C-O) anti-bonding orbital that weakens the respective bonds. The electron density of dimethylamino fragment $(\sim 1.99$ e) demonstrates clearly the strong delocalization. Additionally, the ED of conjugated bond of $3 \mathrm{H}$-chromene ring $(\sim 1.98 \mathrm{e})$ shows clearly a strong delocalization inside the compound [59].

Table 3. Selected second-order perturbation energies $\mathrm{E}^{(2)}$ associated with $\mathrm{i} \rightarrow \mathrm{j}$ delocalization in gas phase.

\begin{tabular}{|c|c|c|c|c|c|c|c|c|}
\hline $\begin{array}{c}\text { Donor } \\
\text { orbital (i) }\end{array}$ & Type & ED/e & $\begin{array}{l}\text { Acceptor } \\
\text { orbital (j) }\end{array}$ & Type & $\mathrm{ED} / \mathrm{e}$ & $\begin{array}{c}\mathrm{E}^{(2)} \\
{[\mathrm{kcal} / \mathrm{mol}]^{\mathrm{a}}}\end{array}$ & $\begin{array}{c}E(j)-E(i) \\
{[a . u .]^{b}}\end{array}$ & $\begin{array}{l}F(i, j) \\
{[\text { a.u. }]^{c}}\end{array}$ \\
\hline S1-C15 & $\sigma$ & 1.97580 & C8-C9 & $\sigma^{*}$ & 0.02256 & 634.30 & 0.03 & 0.127 \\
\hline S2-C15 & $\sigma$ & 1.98331 & C8-C9 & $\sigma^{*}$ & 0.02256 & 1495.44 & 0.12 & 0.376 \\
\hline S2-C15 & $\sigma$ & 1.98331 & C16-H11 & $\sigma^{*}$ & 0.01111 & 718.46 & 0.30 & 0.412 \\
\hline N1-C15 & $\sigma$ & 1.98913 & C8-C9 & $\sigma^{*}$ & 0.02256 & 729.01 & 0.25 & 0.386 \\
\hline N1-C15 & $\sigma$ & 1.98913 & C16-H11 & $\sigma^{*}$ & 0.01111 & 1001.38 & 0.43 & 0.587 \\
\hline N1-C16 & $\sigma$ & 1.98641 & C8-C9 & $\sigma^{*}$ & 0.02256 & 872.35 & 0.13 & 0.303 \\
\hline N1-C16 & $\sigma$ & 1.98641 & C16-H11 & $\sigma^{*}$ & 0.01111 & 572.41 & 0.31 & 0.376 \\
\hline N1-C17 & $\sigma$ & 1.98352 & C8-C9 & $\sigma^{*}$ & 0.02256 & 3068.96 & 0.06 & 0.377 \\
\hline N1-C17 & $\sigma$ & 1.98352 & C16-H11 & $\sigma^{*}$ & 0.01111 & 3399.96 & 0.24 & 0.800 \\
\hline $\mathrm{C} 1-\mathrm{C} 2$ & $\sigma$ & 1.97713 & C5-C6 & $\pi^{*}$ & 1.55092 & 1355.02 & 0.12 & 0.409 \\
\hline $\mathrm{C} 1-\mathrm{C} 2$ & $\sigma$ & 1.97713 & C8-C9 & $\sigma^{*}$ & 0.02256 & 541.72 & 0.23 & 0.318 \\
\hline
\end{tabular}




\begin{tabular}{|c|c|c|c|c|c|c|c|c|}
\hline $\mathrm{C} 1-\mathrm{C} 2$ & $\sigma$ & 1.97713 & C16-H11 & $\sigma^{*}$ & 0.01111 & 343.71 & 0.41 & 0.337 \\
\hline $\mathrm{C} 11-\mathrm{C} 12$ & $\pi$ & 1.80618 & $\mathrm{O} 2-\mathrm{C} 13$ & $\sigma^{*}$ & 0.01287 & 2130.49 & 1.54 & 1.694 \\
\hline $\mathrm{C} 11-\mathrm{C} 12$ & $\pi$ & 1.80618 & N1-C17 & $\sigma^{*}$ & 0.02186 & 461.80 & 2.40 & 0.984 \\
\hline $\mathrm{C} 11-\mathrm{C} 12$ & $\pi$ & 1.80618 & C1-C6 & $\sigma^{*}$ & 0.02327 & 592.10 & 2.54 & 1.144 \\
\hline C11-C12 & $\pi$ & 1.80618 & $\mathrm{C} 2-\mathrm{H} 2$ & $\sigma^{*}$ & 0.01389 & 21144.90 & 0.34 & 2.504 \\
\hline $\mathrm{C} 11-\mathrm{C} 12$ & $\pi$ & 1.80618 & $\mathrm{C} 3-\mathrm{C} 4$ & $\sigma^{*}$ & 0.01442 & 3335.32 & 1.36 & 1.990 \\
\hline $\mathrm{C} 11-\mathrm{C} 12$ & $\pi$ & 1.80618 & C5-C6 & $\pi^{*}$ & 1.55092 & 934.01 & 1.87 & 1.268 \\
\hline $\mathrm{C} 11-\mathrm{C} 12$ & $\pi$ & 1.80618 & C6-C10 & $\sigma^{*}$ & 0.02324 & 569.48 & 2.58 & 1.132 \\
\hline $\mathrm{C} 11-\mathrm{C} 12$ & $\pi$ & 1.80618 & C8-C9 & $\sigma^{*}$ & 0.02256 & 1527.07 & 1.98 & 1.625 \\
\hline $\mathrm{C} 11-\mathrm{C} 12$ & $\pi$ & 1.80618 & $\mathrm{C} 11-\mathrm{C} 12$ & $\sigma^{*}$ & 0.01946 & 303.11 & 2.60 & 0.829 \\
\hline $\mathrm{C} 11-\mathrm{C} 12$ & $\pi$ & 1.80618 & $\mathrm{C} 11-\mathrm{C} 12$ & $\pi^{*}$ & 0.17312 & 414.77 & 2.25 & 0.867 \\
\hline C11-C12 & $\pi$ & 1.80618 & C14-H9 & $\sigma^{*}$ & 0.04360 & 644.07 & 2.32 & 1.133 \\
\hline C11-C12 & $\pi$ & 1.80618 & C16-H11 & $\sigma^{*}$ & 0.01111 & 1717.75 & 2.16 & 1.805 \\
\hline $\mathrm{C} 11-\mathrm{C} 12$ & $\pi$ & 1.80618 & C17-H14 & $\sigma^{*}$ & 0.01317 & 1071.97 & 3.38 & 1.781 \\
\hline C16-H10 & $\sigma$ & 1.98990 & C5-C6 & $\pi^{*}$ & 1.55092 & 393.95 & 0.34 & 0.371 \\
\hline C16-H10 & $\sigma$ & 1.98990 & C8-C9 & $\sigma^{*}$ & 0.02256 & 1719.49 & 0.45 & 0.790 \\
\hline C16-H10 & $\sigma$ & 1.98990 & C16-H11 & $\sigma^{*}$ & 0.01111 & 1906.38 & 0.63 & 0.979 \\
\hline C17-H13 & $\sigma$ & 1.99069 & C11-C12 & $\pi^{*}$ & 0.17312 & 405.51 & 0.18 & 0.254 \\
\hline C17-H13 & $\sigma$ & 1.99069 & C14-H9 & $\sigma^{*}$ & 0.04360 & 319.46 & 0.25 & 0.254 \\
\hline C17-H13 & $\sigma$ & 1.99069 & C16-H11 & $\sigma^{*}$ & 0.01111 & 5450.36 & 0.10 & 0.648 \\
\hline C17-H14 & $\sigma$ & 1.98811 & $\mathrm{C} 11-\mathrm{C} 12$ & $\pi^{*}$ & 0.17312 & 431.89 & 0.17 & 0.251 \\
\hline C17-H14 & $\sigma$ & 1.98811 & C14-H9 & $\sigma^{*}$ & 0.04360 & 341.72 & 0.23 & 0.255 \\
\hline C17-H14 & $\sigma$ & 1.98811 & C16-H11 & $\sigma^{*}$ & 0.01111 & 5664.53 & 0.08 & 0.609 \\
\hline C17-H14 & $\sigma$ & 1.98811 & C17-H14 & $\sigma^{*}$ & 0.01317 & 257.49 & 1.30 & 0.516 \\
\hline C17-H15 & $\sigma$ & 1.98787 & C1-C6 & $\sigma^{*}$ & 0.02327 & 1140.73 & 0.04 & 0.186 \\
\hline C17-H15 & $\sigma$ & 1.98787 & C6-C10 & $\sigma^{*}$ & 0.02324 & 1422.13 & 0.09 & 0.315 \\
\hline C17-H15 & $\sigma$ & 1.98787 & $\mathrm{C} 11-\mathrm{C} 12$ & $\sigma^{*}$ & 0.01946 & 1017.78 & 0.10 & 0.281 \\
\hline S1 & $\mathrm{LP}(1)$ & 1.97153 & $\mathrm{C} 8-\mathrm{C} 9$ & $\sigma^{*}$ & 0.02256 & 342.86 & 0.02 & 0.081 \\
\hline $\mathrm{S} 2$ & $\mathrm{LP}(1)$ & 1.97746 & $\mathrm{C} 8-\mathrm{C} 9$ & $\sigma^{*}$ & 0.02256 & 1656.20 & 0.10 & 0.360 \\
\hline $\mathrm{S} 2$ & $\mathrm{LP}(1)$ & 1.97746 & C16-H11 & $\sigma^{*}$ & 0.01111 & 496.22 & 0.28 & 0.331 \\
\hline $\mathrm{S} 2$ & $\mathrm{LP}(3)$ & 1.52194 & $\mathrm{C} 15$ & $\mathrm{LP}^{*}(1)$ & 0.98014 & 563.69 & 0.02 & 0.108 \\
\hline $\mathrm{O} 2-\mathrm{C} 13$ & $\pi^{*}$ & 0.29368 & $\mathrm{C} 1-\mathrm{H} 1$ & $\sigma^{*}$ & 0.01414 & 659.94 & 24.67 & 9.181 \\
\hline $\mathrm{O} 2-\mathrm{C} 13$ & $\pi^{*}$ & 0.29368 & $\mathrm{C} 2-\mathrm{H} 2$ & $\sigma^{*}$ & 0.01389 & 542.04 & 25.08 & 8.392 \\
\hline $\mathrm{O} 2-\mathrm{C} 13$ & $\pi^{*}$ & 0.29368 & $\mathrm{C} 3-\mathrm{C} 4$ & $\sigma^{*}$ & 0.01442 & 371.63 & 26.09 & 7.082 \\
\hline $\mathrm{O} 2-\mathrm{C} 13$ & $\pi^{*}$ & 0.29368 & $\mathrm{C} 3-\mathrm{C} 4$ & $\pi^{*}$ & 0.27123 & 3841.97 & 19.48 & 14.530 \\
\hline $\mathrm{O} 2-\mathrm{C} 13$ & $\pi^{*}$ & 0.29368 & C5-C6 & $\pi^{*}$ & 1.55092 & 400.08 & 26.61 & 4.740 \\
\hline
\end{tabular}




\begin{tabular}{|c|c|c|c|c|c|c|c|c|}
\hline $\mathrm{O} 2-\mathrm{C} 13$ & $\pi^{*}$ & 0.29368 & $\mathrm{C} 17-\mathrm{H} 14$ & $\sigma^{*}$ & 0.01317 & 302.73 & 28.12 & 6.649 \\
\hline $\mathrm{O} 2-\mathrm{C} 13$ & $\pi^{*}$ & 0.29368 & C17-H15 & $\sigma^{*}$ & 0.01164 & 2690.23 & 18.61 & 16.166 \\
\hline $\mathrm{C} 3-\mathrm{C} 4$ & $\pi^{*}$ & 0.27123 & $\mathrm{C} 1-\mathrm{H} 1$ & $\sigma^{*}$ & 0.01414 & 774.37 & 5.19 & 4.739 \\
\hline $\mathrm{C} 3-\mathrm{C} 4$ & $\pi^{*}$ & 0.27123 & $\mathrm{C} 2-\mathrm{H} 2$ & $\sigma^{*}$ & 0.01389 & 686.92 & 5.60 & 4.636 \\
\hline $\mathrm{C} 3-\mathrm{C} 4$ & $\pi^{*}$ & 0.27123 & $\mathrm{C} 3-\mathrm{C} 4$ & $\sigma^{*}$ & 0.01442 & 359.12 & 6.61 & 3.640 \\
\hline $\mathrm{C} 3-\mathrm{C} 4$ & $\pi^{*}$ & 0.27123 & C5-C6 & $\pi^{*}$ & 1.55092 & 342.60 & 7.13 & 2.305 \\
\hline C5-C6 & $\pi^{*}$ & 0.46141 & $\mathrm{~N} 1-\mathrm{C} 17$ & $\sigma^{*}$ & 0.02186 & 300.63 & 0.53 & 0.726 \\
\hline C5-C6 & $\pi^{*}$ & 0.46141 & C8-C9 & $\sigma^{*}$ & 0.02256 & 1480.79 & 0.11 & 0.740 \\
\hline C5-C6 & $\pi^{*}$ & 0.46141 & C9-C10 & $\pi^{*}$ & 0.23065 & 306.38 & 0.52 & 0.603 \\
\hline C5-C6 & $\pi^{*}$ & 0.46141 & $\mathrm{C} 11-\mathrm{C} 12$ & $\sigma^{*}$ & 0.01946 & 346.70 & 0.72 & 0.911 \\
\hline C5-C6 & $\pi^{*}$ & 0.46141 & C11-C12 & $\pi^{*}$ & 0.17312 & 473.47 & 0.38 & 0.669 \\
\hline C5-C6 & $\pi^{*}$ & 0.46141 & C14-H9 & $\sigma^{*}$ & 0.04360 & 570.34 & 0.44 & 0.893 \\
\hline C5-C6 & $\pi^{*}$ & 0.46141 & C16-H11 & $\sigma^{*}$ & 0.01111 & 1108.24 & 0.29 & 1.041 \\
\hline C9-C10 & $\pi^{*}$ & 0.23065 & N1-C17 & $\sigma^{*}$ & 0.02186 & 1285.15 & 0.02 & 0.359 \\
\hline C11-C12 & $\pi^{*}$ & 0.17312 & $\mathrm{C} 11-\mathrm{C} 12$ & $\sigma^{*}$ & 0.01946 & 499.63 & 0.07 & 0.492 \\
\hline
\end{tabular}

${ }^{a} E^{(2)}$, energy of hyper-conjugative interactions.

${ }^{\mathrm{b}}$ Energy difference between donor and acceptor i and j NBO orbitals.

${ }^{\mathrm{c}} \mathrm{F}_{\mathrm{ij}}$ is the Fock matrix element between $\mathrm{i}$ and $\mathrm{j}$ NBO orbitals.

The hyperconjugative interactions of $\sigma \rightarrow \sigma^{*}$ and $\sigma \rightarrow \pi^{*}$ occur in various bonds in the compound. As an example, the hyperconjugative interactions of $\sigma(\mathrm{N} 1-\mathrm{C} 15)$ distribute to $\sigma^{*}(\mathrm{C} 16-\mathrm{H} 11), \quad \sigma^{*}(\mathrm{C} 1-\mathrm{C} 6), \quad \sigma^{*}(\mathrm{C} 8-\mathrm{C} 9)$ and $\pi^{*}(\mathrm{C} 11-\mathrm{C} 12)$. In case of $\sigma(\mathrm{C} 16-\mathrm{H} 10)$ orbital, the $\sigma^{*}(\mathrm{C} 8-\mathrm{C} 9)$ and $\sigma^{*}(\mathrm{C} 16-\mathrm{H} 11)$ show stabilization energy of $1719.49 \mathrm{kcal} / \mathrm{mol}$ and $1906.38 \mathrm{kcal} / \mathrm{mol}$. Also for $\sigma(\mathrm{C} 17-\mathrm{H} 13)$ and $\sigma(\mathrm{C} 17-\mathrm{H} 14)$ orbitals, the $\sigma^{*}(\mathrm{C} 16-\mathrm{H} 11)$ show stabilization energy of $5450.36 \mathrm{kcal} / \mathrm{mol}$ and $5664.53 \mathrm{kcal} / \mathrm{mol}$, respectively. The intramolecular hyperconjugative interactions of $\sigma(\mathrm{C} 17-\mathrm{H} 15)$ distribute to the $\sigma^{*}(\mathrm{C} 1-\mathrm{C} 6), \sigma^{*}(\mathrm{C} 6-\mathrm{C} 10)$ and $\sigma^{*}(\mathrm{C} 11-\mathrm{C} 12)$ resulting in a stabilization of $1140.73 \mathrm{kcal} / \mathrm{mol}$, $1422.13 \mathrm{kcal} / \mathrm{mol}$ and $1017.78 \mathrm{kcal} / \mathrm{mol}$.

The other hyperconjugative interaction of the $\sigma(\mathrm{C} 1-\mathrm{C} 2)$ enhanced further conjugate with antibonding orbital of $\pi^{*}(\mathrm{C} 5-\mathrm{C} 6)$ and $\sigma^{*}(\mathrm{C} 6-\mathrm{C} 10)$ which results in strong delocalizations of $1355.02 \mathrm{kcal} / \mathrm{mol}$ and $141.88 \mathrm{kcal} / \mathrm{mol}$, respectively.

In addition, the $\pi^{*}(\mathrm{O} 2-\mathrm{C} 13)$ NBO conjugates with respective bonds of $\pi^{*}(\mathrm{C} 3-\mathrm{C} 4)$ and

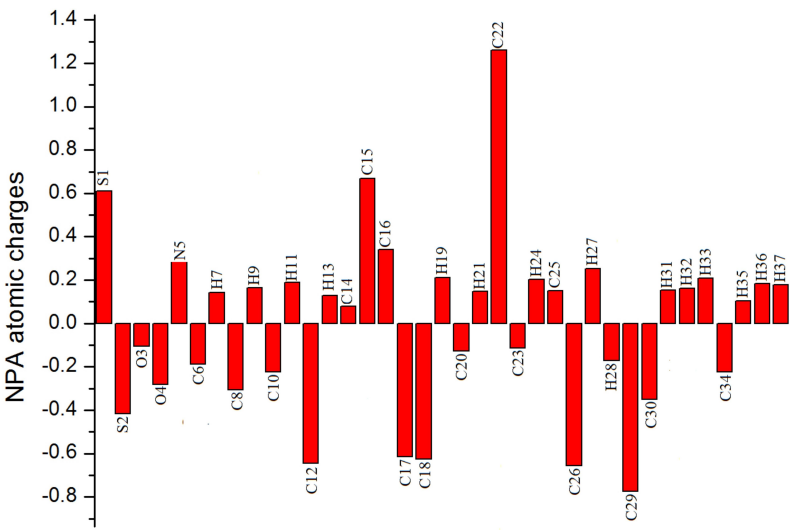

Fig. 4. Natural charges of (3-Oxo-3H-benzo[f] chromen-1-yl) methyl N,N-dimethylcarbamodithioate compound.

$\sigma^{*}(\mathrm{C} 17-\mathrm{H} 15)$ result in an enormous stabilization of $3841.97 \mathrm{kcal} / \mathrm{mol}$ and $2690.23 \mathrm{kcal} / \mathrm{mol}$, respectively. The $\pi^{*}(\mathrm{C} 5-\mathrm{C} 6)$ bond interacts with $\sigma^{*}(\mathrm{C} 8-\mathrm{C} 9)$ and $\sigma^{*}(\mathrm{C} 16-\mathrm{H} 11)$ with energies of $1480.79 \mathrm{kcal} / \mathrm{mol}$ and $1108.24 \mathrm{kcal} / \mathrm{mol}$, respectively. This enhances further conjugate with antibonding orbital from $\pi^{*}(\mathrm{C} 9-\mathrm{C} 10) \rightarrow \sigma^{*}$ (N1-C17), which results in strong delocalization of $1285.15 \mathrm{kcal} / \mathrm{mol}$. 
Table 4. Atomic charge of the title compound in gas phase and solution phase.

\begin{tabular}{|c|c|c|c|c|c|}
\hline \multirow{2}{*}{ Atom } & \multirow{2}{*}{$\begin{array}{c}\text { In gas phase } \\
\text { B3LYP }\end{array}$} & \multicolumn{4}{|c|}{ In solution phase B3LYP } \\
\hline & & $\begin{array}{l}\text { chloroform } \\
(\epsilon=4.71)\end{array}$ & $\begin{array}{c}\text { ethanol } \\
(\epsilon=24.55\end{array}$ & $\begin{array}{c}\text { DMSO } \\
(\epsilon=46.82)\end{array}$ & $\begin{array}{c}\text { water } \\
(\epsilon=78.36)\end{array}$ \\
\hline S1 & 0.60956 & 0.537027 & 0.478449 & 0.475604 & 0.474265 \\
\hline $\mathrm{S} 2$ & -0.41615 & -0.478779 & -0.517133 & -0.521399 & -0.523617 \\
\hline O1 & -0.10548 & -0.117913 & -0.122201 & -0.122873 & -0.123183 \\
\hline $\mathrm{O} 2$ & -0.28113 & -0.357899 & -0.385822 & -0.389277 & -0.390891 \\
\hline N1 & 0.28536 & 0.298592 & 0.307627 & 0.309635 & 0.310459 \\
\hline $\mathrm{C} 1$ & -0.18763 & -0.211948 & -0.230014 & -0.231313 & -0.231804 \\
\hline H1 & 0.14204 & 0.167190 & 0.176634 & 0.177789 & 0.178326 \\
\hline $\mathrm{C} 2$ & -0.30524 & -0.340560 & -0.360467 & -0.361857 & -0.362547 \\
\hline $\mathrm{H} 2$ & 0.16439 & 0.185189 & 0.192497 & 0.193424 & 0.193855 \\
\hline C3 & -0.22452 & -0.215689 & -0.188075 & -0.186689 & -0.186009 \\
\hline H3 & 0.18804 & 0.208438 & 0.216478 & 0.217452 & 0.217904 \\
\hline $\mathrm{C} 4$ & -0.64326 & -0.669077 & -0.687328 & -0.688431 & -0.688799 \\
\hline $\mathrm{H} 4$ & 0.12792 & 0.146120 & 0.142398 & 0.142554 & 0.142555 \\
\hline $\mathrm{C} 5$ & 0.08003 & 0.062580 & 0.053604 & 0.052257 & 0.051574 \\
\hline C6 & 0.66788 & 0.642047 & 0.626788 & 0.625929 & 0.625547 \\
\hline $\mathrm{C} 7$ & 0.34132 & 0.366547 & 0.382597 & 0.382524 & 0.382460 \\
\hline $\mathrm{C} 8$ & -0.61457 & -0.623369 & -0.655181 & -0.656349 & -0.656935 \\
\hline C9 & -0.62482 & -0.662370 & -0.683429 & -0.684688 & -0.685298 \\
\hline H5 & 0.21109 & 0.225034 & 0.229047 & 0.229527 & 0.229749 \\
\hline $\mathrm{C} 10$ & -0.12789 & -0.135643 & -0.121869 & -0.121684 & -0.121666 \\
\hline H6 & 0.14697 & 0.174296 & 0.184445 & 0.185690 & 0.186265 \\
\hline $\mathrm{C} 11$ & 1.26064 & 1.321272 & 1.340740 & 1.341024 & 1.341092 \\
\hline $\mathrm{C} 12$ & -0.11441 & -0.128612 & -0.131286 & -0.132754 & -0.133329 \\
\hline $\mathrm{H} 7$ & 0.20208 & 0.194343 & 0.180341 & 0.179997 & 0.179778 \\
\hline $\mathrm{C} 13$ & 0.14974 & 0.178211 & 0.174948 & 0.176519 & 0.177132 \\
\hline C14 & -0.65621 & -0.600780 & -0.524466 & -0.519846 & -0.517605 \\
\hline H8 & 0.25195 & 0.260395 & 0.262317 & 0.263060 & 0.263432 \\
\hline H9 & -0.17049 & -0.124575 & -0.065318 & -0.061254 & -0.059193 \\
\hline $\mathrm{C} 15$ & -0.77419 & -0.755970 & -0.747506 & -0.746435 & -0.745892 \\
\hline $\mathrm{C} 16$ & -0.35031 & -0.355090 & -0.348341 & -0.348504 & -0.348327 \\
\hline H10 & 0.15430 & 0.171636 & 0.177946 & 0.178740 & 0.179087 \\
\hline H11 & 0.16234 & 0.171409 & 0.177508 & 0.177157 & 0.177092 \\
\hline H12 & 0.20873 & 0.214148 & 0.211118 & 0.211960 & 0.212235 \\
\hline $\mathrm{C} 17$ & -0.22322 & -0.230832 & -0.237464 & -0.238590 & -0.239117 \\
\hline H13 & 0.10379 & 0.123579 & 0.130472 & 0.131457 & 0.131906 \\
\hline H14 & 0.18292 & 0.181195 & 0.183180 & 0.183424 & 0.183578 \\
\hline H15 & 0.17838 & 0.179857 & 0.176768 & 0.176222 & 0.175921 \\
\hline
\end{tabular}

The stronger intramolecular hyper- $\sigma^{*}(\mathrm{C} 3-\mathrm{C} 4) \quad(3335.32 \mathrm{kcal} / \mathrm{mol}), \quad \sigma^{*}(\mathrm{C} 8-\mathrm{C} 9)$ conjugative interactions of $\pi$-electrons $(1527.07 \quad \mathrm{kcal} / \mathrm{mol}), \quad \sigma^{*}(\mathrm{C} 16-\mathrm{H} 11)$ with the greatest energy contribute to $(1717.75 \quad \mathrm{kcal} / \mathrm{mol}), \quad \sigma^{*}(\mathrm{C} 17-\mathrm{H} 14)$ $\mathrm{C} 11-\mathrm{C} 12 \rightarrow \sigma^{*}(\mathrm{C} 2-\mathrm{H} 2) \quad(21144.90 \quad \mathrm{kcal} / \mathrm{mol}), \quad(1071.97 \mathrm{kcal} / \mathrm{mol}), \pi^{*}(\mathrm{C} 5-\mathrm{C} 6)(934.01 \mathrm{kcal} / \mathrm{mol})$. 
The interaction energy related to the resonance in the present molecule involves electron density transfer from a lone pair of S2 to antibonding $\sigma^{*}(\mathrm{C} 8-\mathrm{C} 9)$ of chromene carbon atoms, resulting in an enormous stabilization (up to $1656.20 \mathrm{kcal} / \mathrm{mol})$. The weaker lone pairs of $\mathrm{S} 1$, $\mathrm{O} 1, \mathrm{O} 2$ and $\mathrm{N} 1$ donate their electrons to the $\sigma, \pi$ and LP(1)-type anti-bonding orbital.

We also calculated atomic charge values of the compound by the natural population analysis (NPA) using the DFT/B3LYP method with the $6-311++\mathrm{G}(\mathrm{d}, \mathrm{p})$ basis set in order to determine the electron population of each atom in the title compound. The natural charges were obtained by natural bond orbital analysis (NBO). NPA charge distribution is shown in Fig. 4. As can be seen, all hydrogen atoms have a net positive charge. The NPA analysis shows that all carbon atoms are negatively charged, except for $\mathrm{C} 8, \mathrm{C} 11$ and $\mathrm{C} 13$ atoms of pyran ring. Among all these atoms, the maximum positive atomic charge is obtained only for $\mathrm{C} 13$ atom of carbonyl group. This is due to the attachment of maximum negatively charged $\mathrm{C} 13=\mathrm{O} 2$ double bond.

\subsection{Atomic charge distributions in gas- phase and in solution phase}

The Mulliken atomic charges [60] for the non-H atoms of the title molecule calculated at the B3LYP/6-311++G(d,p) level in gas-phase are presented in Table 4. To investigate the solvent effect on the atomic charge distribution of the title molecule, PCM method has been used. The results obtained for four selected solvents (chloroform, ethanol, dmso and water) are listed in Table 4.

The Mulliken atomic charges show that the carbon atoms attached to hydrogen atoms are negative, whereas $\mathrm{C} 5, \mathrm{C} 6, \mathrm{C} 7, \mathrm{C} 11$ atoms and C13 (adjacent to the oxygen atoms) are positively charged in the whole phase. The other carbon atoms have more negative atomic charges whereas all the hydrogen atoms have positive charges except for H9. Among all the atoms, the maximum positive atomic charge is obtained only for $\mathrm{C} 11$ atom of carbonyl group. This is due to the attachment of the most negatively charged $\mathrm{C} 14$ atom. In the gas phase, S1, C6 and $\mathrm{H} 7$ atoms have larger positive atomic charges while $\mathrm{C} 3, \mathrm{C} 14, \mathrm{H} 9$ and $\mathrm{C} 15$ atoms have larger negative atomic charges. This behavior may be the result of electronegativity differecences between bonded atoms and the resultant bond character. This method and the NPA analysis predict the same tendencies.

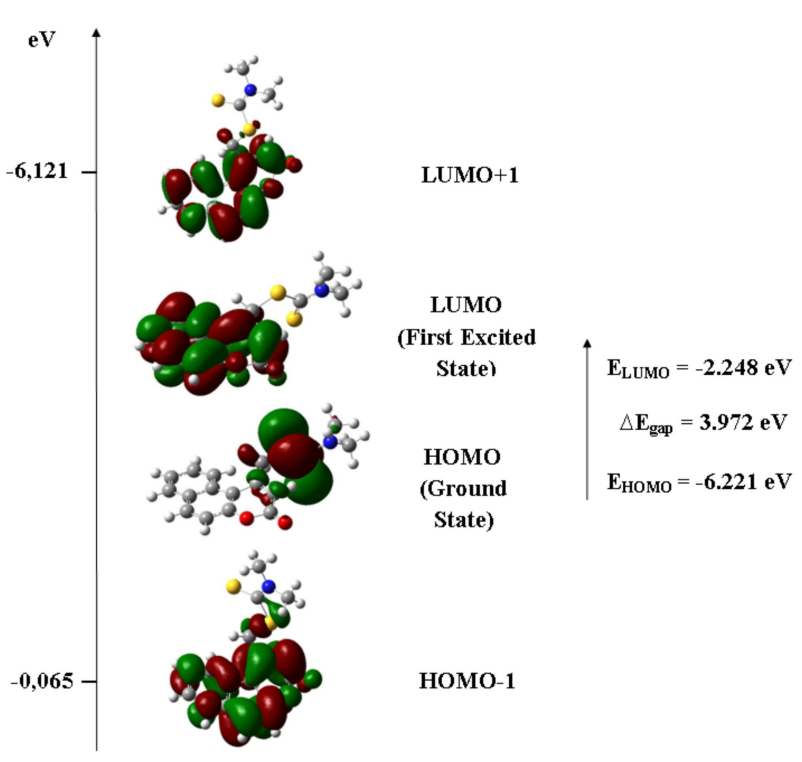

Fig. 5. Molecular orbital surfaces and energy levels (given in parentheses) for the HOMO - 1, HOMO, LUMO and LUMO +1 of (3Oxo-3H-benzo[f]chromen-1-yl) methyl $\mathrm{N}, \mathrm{N}$-dimethylcarbamodithioate computed at B3LYP/6-311++G(d,p) level.

On the other hand, it has been found that, in solution-phase, the atomic charge values of the S2, $\mathrm{O} 2, \mathrm{~N} 1, \mathrm{C} 1, \mathrm{C} 2, \mathrm{C} 4, \mathrm{C} 7, \mathrm{C} 8, \mathrm{C} 9$ and $\mathrm{C} 11$ atoms are larger than those in the gas-phase and their atomic charge values increase with the increase in the polarity of the solvent, but the values of S1, C6, $\mathrm{H} 7, \mathrm{C} 3, \mathrm{C} 14, \mathrm{H} 9$ and $\mathrm{C} 15$ atoms decrease with the increasing polarity of the solvent. The coordination of these atoms is changing in different solvents, which may be helpful when one wishes to use this molecule to construct interesting metal complexes with different coordinate geometries [61]. 


\subsection{Frontier molecular orbital analysis}

The frontier molecular orbitals constitue a basic building block in electric and optical properties as well as in UV-Vis spectra and chemical reactions [62]. In this study, we found that the most energetic method is B3LYP with $-45136.013 \mathrm{eV}$ energy followed by B3PW91 with $-45124.020 \mathrm{eV}$ energy and then HF with $-44951.761 \mathrm{eV}$ energy. Fig. 5 shows the distributions and energy levels of the HOMO and LUMO orbitals, computed using the most energetic method (B3LYP) for the title compound. Both HOMOs and the LUMOs are mostly of the $\pi$-antibonding type and thus, the electronic transitions from HOMO to LUMO may result from the contribution of $\pi-\pi^{*}$ bands [63].
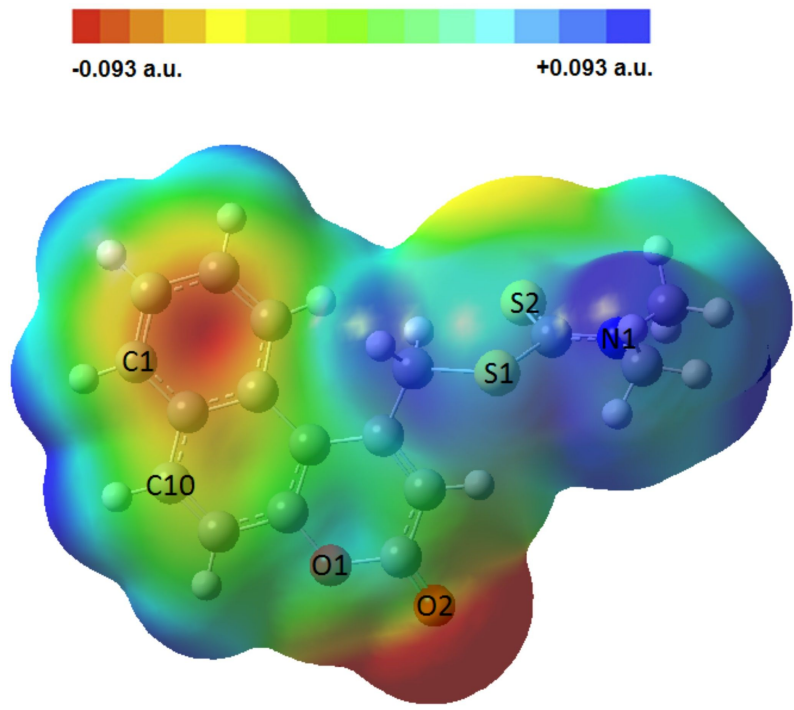

Fig. 6. The total electron density mapped with electrostatic potential surface of (3-Oxo$3 \mathrm{H}$-benzo[f]chromen-1-yl) methyl N,Ndimethylcarbamodithioate compound.

As can be seen from Fig. 5, for the HOMOs, the electrons are delocalized on the sulfur atoms. For the LUMOs, the electrons are mainly delocalized on the 3-oxo-3H-chromen ring. The energy separation between the HOMO and LUMO is $3.972 \mathrm{eV}$. Also chemical hardness and stability can be calculated from the HOMO-LUMO gap and have been found to be $1.986 \mathrm{eV}$ and $0.252 \mathrm{eV}^{-1}$, respectively [64].

\subsection{Molecular electrostatic potential analysis}

Molecular electrostatic potential (MEP) is related to ED and is a very useful tool for identifying the sites for electrophilic and nucleophilic reactions as well as hydrogen bonding interactions $[65,66]$.

In majority of MEP analyses, the maximum negative region which is the preferred site for electrophilic attack is shown in red color, the maximum positive region which is the preferred site for nucleophilic attack is shown in blue color. The MEP displays molecular size, shape as well as positive, negative and neutral electrostatic potential regions in terms of color grading and is very useful in investigating a molecular structure with its physiochemical property relationship [67]. In this study, 3D plot of MEP of the title compound is shown in Fig. 6.

As can be seen from Fig. 6, the negative regions in the molecule were found around the keto group (O2 atom) and inside the benzene ring. The negative $\mathrm{V}(\mathrm{r})$ values are -0.093 a.u. for $\mathrm{O} 2$ atom which is the most negative region and -0.043 a.u. for the inside region of benzene ring. Therefore, we can predict that an electrophile preferably can attack the title compound at the $\mathrm{O} 2$ position.

Meanwhile, looking at the map in Fig. 6, a possible site for nucleophilic processes is predicted on the hydrogens of dimethylamino fragment with a value of +0.057 a.u. The MEP results of the title compound are in agreement with the literature $[67,68]$. According to these calculated results, the MEP map shows that the most negative potential site is on keto group and the most positive potential sites are around the hydrogen atoms.

\subsection{Thermodynamic properties}

On the basis of B3LYP/6-311++G(d,p) vibrational analysis and statistical thermodynamics, the standard thermodynamic functions: entropy $\left(\mathrm{S}_{\mathrm{m}}^{0}\right)$, heat capacity $\left(\mathrm{C}_{\mathrm{p}, \mathrm{m}}^{0}\right)$ and enthalpy $\left(\mathrm{H}_{\mathrm{m}}^{0}\right)$ were obtained and listed in Table 5.

The scale factor for frequencies, which has been used for an accurate prediction of the thermodynamic functions, is 0.96 . Table 5 shows that 
Table 5. Thermodynamic properties at different temperatures at B3LYP/6-311++G(d,p) level.

\begin{tabular}{cccc}
\hline $\begin{array}{c}\mathrm{T} \\
\mathrm{K}]\end{array}$ & $\begin{array}{c}\mathrm{H}_{\mathrm{m}}^{0} \\
{\left[\mathrm{kcal} \cdot \mathrm{mol}^{-1}\right]}\end{array}$ & $\begin{array}{c}\mathrm{C}_{\mathrm{p}, \mathrm{m}}^{0} \\
{\left[\mathrm{cal} \cdot \mathrm{mol}^{-1} \mathrm{~K}^{-1}\right]}\end{array}$ & $\begin{array}{c}\mathrm{S}_{\mathrm{m}}^{0} \\
{\left[\mathrm{cal} \cdot \mathrm{mol}^{-1} \cdot \mathrm{K}^{-1}\right]}\end{array}$ \\
\hline \hline 200 & 7.173 & 55.754 & 128.531 \\
250 & 10.507 & 67.569 & 142.683 \\
298.15 & 14.302 & 78.847 & 155.889 \\
300 & 14.459 & 79.273 & 156.398 \\
350 & 19.013 & 90.477 & 169.783 \\
400 & 24.133 & 100.885 & 182.816 \\
450 & 29.775 & 110.354 & 195.488 \\
500 & 35.888 & 118.864 & 207.775 \\
550 & 42.423 & 126.474 & 219.662 \\
600 & 49.334 & 133.274 & 231.133 \\
\hline
\end{tabular}

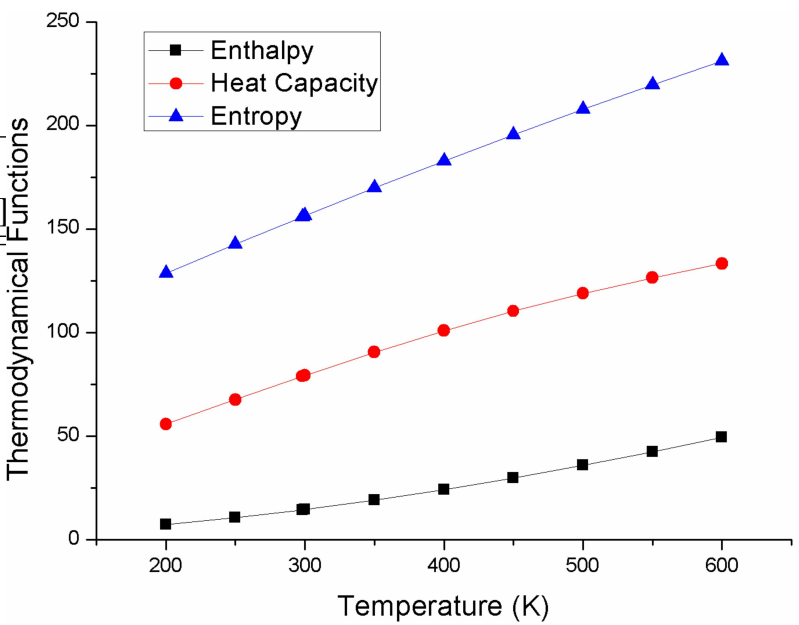

the $\mathrm{S}_{\mathrm{m}}^{0}, \mathrm{C}_{\mathrm{p}, \mathrm{m}}^{0}$ and $\mathrm{H}_{\mathrm{m}}^{0}$ increase with temperature from $200.00 \mathrm{~K}$ to $600.00 \mathrm{~K}$, because the intensities of the molecular vibrations increase with the increasing temperature.

The correlations between these thermodynamic properties and temperature $\mathrm{T}$ are shown in Fig. 7. The correlation equations are as follows:

$C_{p, m}^{0}=-1.85521+0.31619 T-1.49867 \times 10^{-4} T^{2} ;$

$\left(R^{2}=0.99985\right)$

$S_{m}^{0}=68.25583+0.31622 T-7.4506 \times 10^{-5} T^{2} ;$

$$
\left(R^{2}=1\right)
$$

$H_{m}^{0}=-1.77879+0.02345 T-1.03268 \times 10^{-4} T^{2} ;$

$\left(R^{2}=0.99994\right)$

These equations will be helpful for the further studies of the title compound.

\section{Conclusions}

The geometric parameters and vibrational frequencies of 3-Oxo-3H-benzo[f]chromen-1-yl) methyl N.N-dimethylcarbamodithioate have been calculated using HF and DFT (B3LYP and B3PW91) methods with 6-311++G(d,p) basis sets. The comparison between the calculated results and

the X-ray experimental data shows that B3LYP method is better than HF and B3PW91 methods in evaluating bond lengths, angles, dihedral angles and vibrational frequencies, in which the experimental and theoretical results support each other [24]. The energy gap between the HOMO and LUMO is very large and this energy separation gives important information about the title compound. The NBO analysis revealed that the $\pi^{*} \rightarrow \pi^{*}$ interactions give the strongest stabilization to the system. On the other hand, it was found that, in gas-phase, the atomic charge values are larger than those in solution-phase and atomic charge values decrease with increasing polarity of the solvent. The correlations between the statistical thermodynamic properties (enthalpy, entropy, heat capacity) and temperatures were also studied. Our calculations are in progress and we hope that the present paper will be useful in designing and synthesis of new materials.

\section{References}

[1] Evans B.E., Rittle K.E., Bock M.G., Dipardo R.M., Freidinger R.M., WhitTER W.L., LUNDELL G.F., Veber D.F., ANDERson P.S., Chang R.S.L., Lotti V.J., Cerino D.J., Chen T.B., Kling P.J., Kunkel K.A., Springer J.P., Hirshfield J., J. Med. Chem., 31 (1988), 2235.

[2] Enraf-Nonius CAD-4 Express '88 Software, EnrafNonius: Delft, Holland, 1988. 
[3] Henriette G., Lorraine L., Bettina H., Clemence D., Kelly D., Irenej K., Mol. Cancer Ther, 3 (2004), 1375.

[4] Laurin P., Ferroud D., Klich M., DupuisHamelin C., Mauvais P., Lassaigne P., BonNeFOY A., Musicki B., Bioorg. Med. Chem. Lett., 9 (1999), 2079.

[5] Fylaktakidou K.C., Hadjipavlou-Litina D.J., Litinas K.E., NiColaides D.N., Curr. Pharm. Des., 10 (2004), 3813(30).

[6] Kwangwoo C., Song-Kyu P., Mook K.H., Yongseok C., MYUng-Hwa K., Chun-Ho P., Bo-Young J., Gyu C.T., Hyun-Moo C., HeEYoon L., HeE H.S., SoOK K.M., KY-Youb N., GYoOnheE H., Bioorg. Med. Chem., 16 (2008), 530.

[7] Sharma P.N., Shoeb A., KaPil R.S., Popli S.P., Indian J. Chem. B, 19 (1980), 938.

[8] Sharma P.N., Shoeb A., Kapil R.S., Popli S.P., Indian J. Chem. B, 17 (1979), 299.

[9] Nareshiumar J., Jiayi X., Ramesh M.K., FuYong D., Guo J.Z., Emmanuel P., J. Med. Chem., 52 (2009), 7544.

[10] Traykova M., Kostova I., Int. J. Pharm., 1 (2005), 29.

[11] Doshi J.M., Tian D., Xing C., J. Med. Chem., 49 (2006), 7731.

[12] AliaA M.K., Manal M.K., Eman K Abd El-All, Heba A.H. Elshemy, Int. J. Pharm. Res. Develop., 4 (2012), 310.

[13] NORTH A.C.T., PHILIPS D.C., MATHEWS F.S., Acta Cryst. A, 24 (1968), 351,

[14] Kamdar N.R., HaVeliwala D.D., Mistry P.T., PATEl S.K., Medic. Chem. Res., 20 (2011), 854.

[15] Sharma P.N., Shoeb A., Kapil R.S., Popli S.P., Phytochemistry, 20 (1981), 335.

[16] Elhafez O.M.A., El Khrisy E.D., Badria F., FATHY A.D., Arch. Pharm. Res., 26 (2003), 686.

[17] Bhat M.A., Siddiqui N., Khan S.A., Acta Pol. Pharm., 65 (2008), 235.

[18] Jones G., Jackson W.R., Choi C., Bergmark W.R., J. Phys. Chem., 89 (1985), 294.

[19] Trenor S.R., Shultz A.R., Love B.J., Long T.E., Chem. Rev., 104 (2004), 3059.

[20] Hung T.T., Lu Y.J., Liao W.Y., HuAnG C.L., IEEE Trans. Magn., 43 (2007), 867.

[21] Kumar K.M., Kour D., Kapoor K., MaHABaleshwaraiah N.M., Kotresh O., Gupta V. K., KAnT R., Acta Cryst. E, 68 (2012), o878.

[22] El-Bayouki K.A., Aly M.M., Mohamed Y.A., BASYOUNI W.M., ABBAS S.Y., WJ Chem., 4 (2009), 161.

[23] Thomas N.A.N.C.Y., Zachariah S.M., Asian J. Pharm. Clin. Res., 6 (2013), 11.

[24] Mahabaleshwaraiah N.M., RaVi H.R., VinduVAhini M., Sreepad H.R., Kotresh O., Acta Cryst. $E, 68$ (2012), o3001.
[25] Frisch M.J., TruCKS G.W., Schlegel H.B., Scuseria G.E., RobB M.A., Cheeseman J.R., Scalmani G., Barone V., Mennucci B., Petersson G.A., Nakatsuji H., Caricato M., Li X., Hratchian H.P., IZMAYlov A.F., Bloino J., ZHENG G., SONNENBERG J.L., HADA M., Ehara M., TOYOTA K., FukUda R., HASEgaWA J., ISHida M., NAKaJima T., Honda Y., KitaO O., Nakai H., Vreven T., Montgomery JR. J.A., Peralta J.E., Ogliaro F., Bearpark M., Heyd J.J., Brothers E., Kudin K.N., Staroverov V.N., Kobayashi R., NORMAND J., RaghaVACHARI K., RENDELl A., BURANT J.C., IYENGAR S.S., Tomasi J., Cossi M., Rega N., Millam J.M., Klene M., Knox J.E., Cross J.B., BAKKen V., Adamo C., Jaramillo J., Gomperts R., StratMANn R.E., YAzyev O., Austin A.J., CAmmi R., POMElli C., OCHTERSKI J.W., MARTIN R.L., Morokuma K., ZaKrzewski V.G., VOTH G.A., SALVADOR P., DANNENBERG J.J., DAPPRICH S., DANIEls A.D., FARKAS O., FORESMAN J.B., ORTIZ J.V., Cioslowski J., Fox D.J., Gaussian 09, Revision C.01, Gaussian, Inc.: Wallingford, CT, 2009.

[26] Dennington R., Keith T., Millam J., GaussView, Version 5, Semichem Inc.: Shawnee Mission, KS, 2009.

[27] ZHURKo G.A., ChemCraft, version 1.6 (build 304), 2009. http: //www. chemcraftprog.com/.

[28] TAnaK H., Agar A.A., BÜYÜKGüngÖr O., Spectrochim. Acta A, 87 (2012), 15.

[29] Sundaraganesan N., Kalaichelvan S., Meganathan C., Joshua B.D., Cornard J., Spectrochim. Acta A, 71 (2008), 898.

[30] Ahmed M.K., Henry B.R., J. Phys. Chem., 90 (1986), 1737.

[31] Ramalingam S., Periandy S., GovindaraJAN M., MOHAN S., Spectrochim. Acta A, 75 (2010), 1308.

[32] Sheldrick G.M., Acta Cryst., A 64 (2008), 112.

[33] Babu P.D., Periandy S., Mohan S., RamaLINGAM S., JAYAPRAKASH B.G., Spectrochim. Acta A, 78 (2011), 168.

[34] Sundaraganesan N., Ilakiamani S., SAleEm H., Wojiciechowski P.M., Michalska D., Spectrochim. Acta A, 61 (2005), 2995.

[35] Krishnakumar V., John Xavier R., Indian J. Pure. Appl. Phys., 41 (2003), 597.

[36] Krishnakumar V., Prabavathi N., Spectrochim. Acta A, 71 (2008), 449.

[37] Altun A., Golcuk K., Kumru M., J. Mol. Struct., 637 (2003), 155.

[38] Singh S.J., Pandey S.M., Indian J. Pure. Appl. Phys., 12 (1974), 300.

[39] Singh R.N., Prasad S.C., Spectrochim. Acta A, 34 (1978), 39.

[40] Silverstein M., Bassler G.C., Morril C., Spectro-scopic Identification of Organic Compounds, $5^{\text {th }}$ Ed., John Wiley \& Sons Inc., Singapore, 1991. 
[41] Altun A., Golcuk K., Kumru M., J. Mol. Struct., 625 (2003), 17.

[42] Durig J.R., Bergana M.M., Phan H.V., J. Raman Spectrosc., 22 (1991), 141.

[43] Litivinov G., Proceedings of the $13^{\text {th }}$ International Conference on Raman Spectroscopy, Würzburg, Germany, 1992.

[44] Govindarajan M., Ganasan K., Periandy S., Mohan S., Spectrochim. Acta A, 76 (2010), 12.

[45] Silverstein R.M., Basseler G.C., Morill C., Spectroscopic Identification of Organic Compounds, Wiley, New York, 1981.

[46] Karakurt T., Dincer M., Çukurovali A., YilMAZ I., J. Mol. Struct., 991 (2011), 186.

[47] Tecklenburg M.M.J., Kosnak D.J., BhatnaGaR A., Mohanty D.K., J. Raman Spectr., 28 (1997), 755.

[48] Pajazk J., Rospenk M., Ramaekers R., Maes G., GŁowiak T., Sobczyk L., Chem. Phys., 278 (2002), 89.

[49] Arivazhagan M., Krishnakumar V., JohnXAVIER R., Ilango V., Balachandran K., Spectrochim. Acta A, 72 (2009), 941.

[50] VARASAnYI G., Vibrational Spectra of Benzene Derivatives, Academic Press, New York, 1969.

[51] Silverstein R.M., Webstor F.X., Spectrometric Identification of Organic Compounds, $6^{\text {th }}$ Ed., John Willey \& Sons, New York, 1998.

[52] Colthup N.B., DAly L.H., Wiberly S.E., Introduction to Infrared and Raman Spectroscopy, $3^{\text {rd }}$ Ed., Academic Press, Boston, MA, 1990.

[53] SocRATEs G., Infrared Characteristic Group Frequencies, John Wiley and Sons, New York, 1980.
[54] James C., Amal Raj A., Reghunathan R., HuBERT JoE I., JAYAKUMAR V.S., J. Raman Spect., 37 (2006), 1381.

[55] LiU J.N., Chen Z.R., YuAN S.F., J. Zhejiang Univ. Sci. B, 6 (2005), 584.

[56] Muthu S., Prasath M., Spectrochim. Acta A, 115 (2013), 789.

[57] Schwenke D.W., Truhlar D.G., J. Chem. Phys., 82 (1985), 2418.

[58] Gutowski M., Chalasinski G., J. Chem. Phys., 98 (1993), 4728.

[59] TANaK H., Agar A.A., BÜYÜKGÜNGÖR O., Spectrochim. Acta A, 118 (2014), 672.

[60] Mulliken R.S., J. Chem. Phys., 23 (1955), 1833.

[61] Jian F.F., Zhao P.S., Bai Z.S., Zhang L., Struct. Chem., 16 (2005), 635.

[62] Fleming I., Frontier Orbitals and Organic Chemical Reactions, Wiley, London, 1976.

[63] Овот I.B., Johnson A.S., Elixir Comp. Chem., 43 (2012), 6658.

[64] PIR H., GÜNAY N., Avci D., TAMer Ö., TARCAN E., Atalay Y., Arab. J. Sci. Eng., 39 (2014), 5799.

[65] Scrocco E., Tomasi J., Adv. Quantum Chem., 11 (1979), 115.

[66] LuQue F.J., Lopez J.M., Orozco M., Theor. Chem. Acc., 103 (2000), 343.

[67] TanaK H., Toy M., J. Mol. Struct., 1068 (2014), 189.

[68] Evecen M., TanaK H., Mater. Sci.-Poland, 34 (2016), 886.

Received 2016-12-27 Accepted 2017-07-06 